\title{
Research on the Construction of Graduate Education Management and Cultivation Mechanism in Universities
}

\author{
Rui Chen \\ Hei Longjiang BaYi Agricultural University, Daqing 163319, Heilongjiang, China. \\ Email: bynd_chenrui@163.com
}

\begin{abstract}
Education has a long history of development. With the rapid development of the economy and the progress of society, the country's demand for talents and the quality of talent training is constantly increasing. The current high degree of education has become the choice of young intellectuals, so graduate education has become the focus of attention. At this stage, the scale of graduate education continues to expand, and more attention should be paid to the strengthening of graduate education in management and training mechanisms in order to facilitate the graduate education, to provide a broad space for the development and adapting to the times. Based on the current situation of graduate education management and training mechanisms in colleges and universities, this article analyzes and researches, hoping to bring a positive effect to graduate education in universities.

Keywords: Graduate Students; Education Management; Training Mechanism

The progress and development of society require the construction of high-quality talents. Our country also pays more and more attention to the cultivation of talents. Colleges and universities, as an important unit for cultivating specialized talents, developing scientific knowledge and serving the society, focus on the cultivation of talents, social economy The development of the university requires the cultivation and delivery of high-quality talents. At present, most undergraduate graduates will choose to continue their studies to improve their academic qualifications. Universities are also constantly expanding the scope and number of graduate student enrollment, so that more graduate students can receive graduate education to meet their needs. Under such circumstances, colleges and universities can only meet the needs of the ever-expanding graduate student population by continuously improving the quality of teaching and management.
\end{abstract}

\section{The current management status of graduate students in China's universities}

Graduate management is an important part related to the cultivation of postgraduate students. At present, graduate management in colleges and universities generally presents difficulties in management, inflexible management systems, and difficulties in implementation that are mainly reflected in the following points: First of all, some graduate students pay attention to work during their graduate studies, and there is a "difficulty between work and study" phenomenon. When the school curriculum conflicts with working hours, students may neglect the course attendance for work attendance, resulting in difficulty in unified teaching and management. Secondly, it is reflected in the management of graduates going out. If graduates need to go out, they usually contact their tutors. The graduate management department does not have enough details, which brings great difficulties to the relevant administrators of the school. It is difficult to implement relevant management rules and regulations during management. Thirdly, the graduate students are all adults and have their own independent thinking. They will not easily inform their parents or mentors of their inner thoughts. It is difficult for parents and mentors to master their ideological status, which leads to failure to find the reason timely

Copyright (C) 2020 Rui Chen

doi: 10.18282/le.v9i5.1261

This is an open-access article distributed under the terms of the Creative Commons Attribution Non-Commercial License

(http://creativecommons.org/licenses/by-nc/4.0/), which permits unrestricted non-commercial use, distribution, and reproduction in any medium, provided the original work is properly cited. 
when problems occur. It can be seen that there are deficiencies in the management of graduate students in Chinese universities, and universities need to actively respond to and solve problems.

\section{Discussion on management methods of graduate education}

\subsection{Establish a people-oriented concept of graduate education}

Graduate education is the highest level of education in the entire education chain, and is a reflection of the scientific research ability and comprehensive ability of colleges and universities as well as humanistic literacy. University graduate management workers should change the management of graduate education. In line with the principle of people-oriented, with the cultivation of graduate students as the center, starting from the heart of the graduate education administrators of colleges and universities, treat each graduate student with heart, and deal with problems from the perspective of graduate students. They should also actively seek the advice of graduate students, which can make the students feel that the school is based on the people-oriented management principle, so as to enhance the recognition of the graduates and their motivation for self-improvement.

\subsection{Strengthen the innovation of graduate education management}

At present, China's colleges and universities have basically established and used various graduate education information management systems. This system masters the basic information of graduate students, makes them familiar with the situation of graduate students, and facilitates the supervision and management of graduate students in study and life. In this system, from the initial enrollment to admission, the daily management of graduate education, teaching management, social basic practice, awarding a degree, to the final graduate employment guidance, these all make graduate education management more efficient and realize the sharing of educational resources.

\subsection{The team of teachers should have scientific research and innovation capabilities}

The people that are most closely connected with graduate students in colleges and universities are the graduate tutors. According to the explicit requirements of the Ministry of Education, the graduate tutor must earnestly perform and implement his responsibilities as a virtuous person, strengthen his basic qualities, and establish a professional concept. They should realize that cultivating outstanding social talents is a fundamental task. Instructors of graduate education in universities should strictly demand themselves and clarify their major social responsibilities. Under the background of the COVID-19 epidemic, the graduate tutor should know how to deal with these emergencies, they need also have the sense of innovation and adaptability, actively explore new research topics, understand social dynamics, and promote their own capabilities in research development and improvement. They should enable the continuous innovation of the team, so that the ability of postgraduates in colleges and universities can be improved and exercised. They are required to actively participate in academic activities and seminars organized by schools or other universities. The team of teachers must keep pace with the times and actively carry out teaching reforms while completing teaching tasks to continuously improve teaching quality. They should understand the real needs of graduate students for subject research, guide graduate students in a timely manner, urge graduate students to learn the basic knowledge, cutting-edge technology and practical applications, etc., to improve graduate students' ability in research, summarizing results and article writing, and help graduate students cultivate the sense of learning and self-innovation.

\section{Measures and research to improve the training mechanism of graduate education}

\subsection{Improve the training mechanism for graduate education}

The purpose of training graduates in universities is to deliver high-quality talents to the country. To ensure the efficient and timely output of these talents, the school should cooperate with the government and relevant enterprises while training graduates in universities. During the training process, universities, governments, and enterprises coordinate with each other and communicate with each other. Graduate education is different from general education. It involves a large number of topics and research and development, and requires a lot of funding and venue support. Government departments should properly provide funding support and project declarations for scientific research in 
universities, and at the same time establish good school-enterprise relations to provide convenient scientific research conditions for the research and development teams of universities. In addition, graduate schools should expand the scale of scholarships and bursaries, increase investment in the construction of a graduate study environment, to reduce students' psychological burden and help them study with peace of mind.

\subsection{Establish an interactive platform for postgraduate information exchange}

The reliable guarantee for the successful implementation of graduate education requires an effective management mechanism. Nowadays, science and technology information is becoming more and more developed. Universities should also deeply understand the importance of establishing online and offline teaching and learning platforms. They should actively introduce information technology, network communication technology, inter-group local teaching systems, and realize online interactive teaching, to ensure effective communication between teachers and graduates. The teaching platform should not only record the basic information of graduate students through registration, so that the graduate student information can be accessed immediately, and resources can be shared, which is convenient for graduate education managers to implement education management. Graduate students can also keep abreast of various academic dynamics and academic activities of the school through the information exchange platform, so that they can participate in a timely manner. The establishment of the platform makes communication between graduate students and teachers more convenient. Universities should constantly adjust graduate education programs in line with their own actual conditions and keep pace with the times.

\subsection{The management and assessment of the postgraduate counselor}

The student tutor is the direct manager of the graduate student and the spiritual mentor of the graduate student, who plays an important guiding role in shaping the character of the graduate student. They help graduate students to establish a correct world outlook, outlook on life, and values, which is the most basic job responsibility as a counselor. The instructor's responsibilities include all aspects of graduate students. In life, it focuses on training graduate students' ability to withstand stress in life. They are good at facing challenges and difficulties. They are not afraid of hardships and can make progress steadily. In terms of learning, they cultivate graduate students to be calm at emergencies and think actively. In terms of mental health, they help graduate students to resolve the emotions in their hearts, to have a correct understanding of themselves, and can always maintain a positive and dialectical attitude towards life. Therefore, the words and deeds of the counselor have a great impact on graduate students, and only by constantly improving their management skills can they become a qualified counselor. In addition, it is necessary to regularly assess the instructors, cultivate their ideological and professional abilities, and check their work abilities in a timely manner.

\section{Conclusion}

The number of postgraduates in the contemporary era has increased dramatically. With the ever-expanding scale of graduate students in colleges and universities, only by advancing with the times and innovative thinking can the quality of graduate education be guaranteed. Colleges and universities should combine their own school-running conditions and advantages, continuously improve the quality of hardware facilities and teaching and research teams, and develop management systems and training goals that are in line with the times, so as to meet the current expanding number of graduate students and enable them to realize values to make more contributions to society and the people.

\section{References}

1. Gao L. On the management system and reform of graduate education. Friends of Humanities 2020; (4): 119.

2. Li T. Research on the development of graduate party members and innovation of education management services in colleges and universities. Industry and Technology Forum 2020; 19(7): 226-227.

3. Li M, Wang Z. Postgraduate education management in China since reform and opening up: achievements and challenges. Education Research of Tsinghua University 2019; 40(5): 105-111. 